\title{
Similar Levels of mRNA from the W1282X and the $\Delta$ F508 Cystic Fibrosis Alleles, in Nasal Epithelial Cells
}

\author{
Tzipora Shoshani, " Eitan Kerem," Amir Szeinberg," Arie Augarten," Yaakov Yahav, \\ David Cohen," Joseph Rivlin," Asher Tal** and Bat sheva Kerem* \\ *Department of Genetics, Hebrew University of Jerusalem, Jerusalem $91904 ;{ }^{\ddagger}$ Department of Pediatrics, Shaare Zedek Medical Center, \\ Jerusalem 91031; \$Department of Pediatrics, Chaim Sheba Medical Center, Tel Aviv 52621; "Department of Ear Nose and Throat, \\ Shaare Zedek Medical Center, Jerusalem 91031; 'Department of Pediatrics, Carmel Hospital, Haifa 34362; and ${ }^{* *}$ Department of \\ Pediatrics, Soroka Medical Center, Beer Sheba 84101, Israel
}

\begin{abstract}
The effect of nonsense mutations on mRNA levels is variable. The levels of some mRNAs are not affected and truncated proteins are produced, while the levels of others are severely decreased and null phenotypes are observed. The effect on mRNA levels is important for the understanding of phenotype-genotype association. Cystic fibrosis (CF) is a lethal autosomal recessive disease with variable clinical presentation. Recently, two CF patients with mild pulmonary disease carrying nonsense mutations (R553X, W1316X) were found to have severe deficiency of mRNA. In the Jewish Ashkenazi CF patient population, $60 \%$ of the chromosomes carry a nonsense mutation, W1282X. Patients homozygous for this mutation have severe disease presentation with variable pulmonary disease. The presence of CF transcripts in a group of patients homozygous and heterozygous for this mutation was studied by reverse transcriptase PCR of various regions of the gene. Subsequent hybridization to specific CF PCR probes and densitometry analysis indicated that the CF mRNA levels in patients homozygous for the W1282X mutation are not significantly decreased by the mutation. mRNA levels were compared for patients heterozygous for the W1282X mutation. The relative levels of mRNA with the W1282X, and the $\Delta F 508$ or the normal alleles, were similar in each patient. These results indicate that the severe clinical phenotype of patients carrying the W1282X mutation is not due to a severe deficiency of mRNA. In addition, the severity, progression, and variability of the pulmonary disease are affected by other, as yet unknown factors. (J. Clin. Invest. 1994. 93:1502-1507.) Key words: cystic fibrosis • termination mutation • W1282X • mRNA levels • genotype-phenotype
\end{abstract}

\section{Introduction}

Nonsense mutations, which code for premature termination of translation, can also affect the levels of mRNA. Some mRNA carrying nonsense mutations are present in normal levels, resulting in the production of truncated proteins $(1,2)$. However, the levels of many other mRNA with nonsense mutations are

Adress correspondence to Dr. Bat sheva Kerem, Genetics Department, Life Sciences Institute, Hebrew University, Jerusalem 91904, Israel

Received for publication 21 April 1993 and in revised form 24 November 1993

J. Clin. Invest.

(c) The American Society for Clinical Investigation, Inc.

$0021-9738 / 94 / 04 / 1502 / 06 \$ 2.00$

Volume 93, April 1994, 1502-1507 severely decreased, resulting in null phenotypes. Decreased mRNA levels due to nonsense mutations have been found in bacteria (3), yeast (4), mice (5), and humans (6-13). Nonsense mutations in the $\beta$-globin gene cause a 40 fold reduction in the half-life of $\beta$-globin mRNA in erythroid cells (14). In the dihydrofolate reductase gene, nonsense mutations reduce the mRNA levels but the transcription and stability of the mature mRNA are normal (15). In some cases, a polar effect is observed. For instance, immunoglobulin $m R N A s$ with nonsense mutations in the $5^{\prime}$ end of their coding regions are 100 -fold less stable than mRNAs with nonsense mutations near the authentic termination codons (16).

In cases in which the termination mutations cause diseases, an understanding of their effects on mRNA stability can aid in understanding the phenotype-genotype association. For example, the absence of $\beta$-globin mRNA in the peripheral blood of patients homozygous for nonsense mutations causes $\beta^{0}$-thalassemia, which is the most severe form of $\beta$-thalassemia (17).

Cystic fibrosis (CF) ${ }^{1}$ is the most frequent autosomal recessive lethal disease in the Caucasian population (18). The disease is characterized mainly by progressive lung disease, pancreatic dysfunction, impaired growth, and elevated sweat chloride (18). The severity of the disease presentation and its rate of progression in the involved organs vary considerably. The gene responsible for the disease has been recently cloned and a major mutation, $\Delta F 508$, which accounts for $70 \%$ of the CF chromosomes, has been identified (19-21). A phenotype-genotype correlation in CF has been suggested, based on haplotype analysis and the different distribution of the $\Delta F 508$ mutation among pancreatic-sufficient and -insufficient patients $(21,22)$. The $\Delta F 508$ mutation was shown to be associated with severe clinical presentation as reflected by early onset, pancreatic insufficiency, early age at diagnosis, poor nutritional status, high sweat chloride levels, and variable pulmonary function (23, 24). Since the identification of the CF gene, $>300$ mutations have been identified worldwide (25). Several of these have been found to be associated with severe form of the disease, while others have been found to be associated with relatively mild presentation (26).

Recently, two CF patients carrying nonsense mutations were reported to have severe deficiency of mRNA transcribed from the nonsense alleles (27). One patient carried two different nonsense mutations, R553X and W1316X, and the second patient was heterozygous for the missense mutation, S549N, and the nonsense mutation, R553X. The R553X nonsense

1. Abbreviations used in this paper: $\mathrm{CF}$, cystic fibrosis; $\mathrm{CFTR}, \mathrm{CF}$ transmembrane regulator; $\mathrm{RT}$, reverse transcriptase. 
mutation is located in the first nucleotide binding fold of the CF transmembrane regulator (CFTR) protein, while the second nonsense mutation, W1316X, is located in the second nucleotide binding fold close to the $3^{\prime}$ end of the gene.

In the Ashkenazi Jewish CF population the frequency of the $\Delta \mathrm{F} 508$ mutation is only $24 \%$. Recently, a major mutation, W1282X, was found in $60 \%$ of the chromosomes carried by patients from this ethnic group (28). This mutation creates a stop codon in exon 20 of the $C F$ gene, which is located in the second nucleotide binding fold of the CFTR protein. Among patients of Jewish Ashkenazi origin $\sim 25 \%$ are homozygous for this nonsense mutation. We recently compared the clinical presentation of patients homozygous for the W1282X mutation and patients heterozygous for both the $\Delta \mathrm{F} 508$ and the W1282X mutations (28). We found that patients in both groups have similar severe disease presentation as reflected by pancreatic insufficiency, high incidence of meconium ileus, early age at diagnosis, poor nutritional status, and variable pulmonary function. In this study we aimed to determine the effect of the nonsense mutation, W1282X, on mRNA levels in order to deepen our understanding of the genotype-phenotype association in CF.

\section{Methods}

Patients and controls. This study included five CF patients homozygous for the W1282X mutation, two CF patients homozygous for the $\Delta \mathrm{F} 508$ mutation, two CF patients heterozygous for both the W1282X and the $\triangle F 508$ mutations, seven parents of the CF patients carrying the W1282X mutation, and a healthy Jewish Ashkenazi who does not carry any of the mutations known to account for $97 \%$ of the CF mutations in this ethnic group. This individual was considered a normal control. The patients' diagnoses had been confirmed before this study. The disease presentation of the patients has been described previously (28).

$R N A$ extraction and single-strand $c D N A$ synthesis. Nasal epithelial cells were scraped from all the individuals studied. The cells were immediately placed in liquid nitrogen. For RNA extraction the cells were resuspended in $300 \mu \mathrm{l} \mathrm{RNAzol}{ }^{\mathrm{Tm}}$ B buffer (BIOTECX Laboratories, Inc.). Total RNA was extracted using the acid-phenol-chloroform method according to the manufacturer's instructions.

RNA was solubilized in $10 \mu$ l diethylpyrocarbonate (DEPC)-treated RNAse-free double-distilled water. $3 \mu \mathrm{l}$ of the RNA solution was added to $2.5 \mu \mathrm{M}$ random hexamer mix (Pharmacia Fine Chemicals, Piscataway, NJ), $1 \mathrm{mM}$ (each) dNTPs (Pharmacia Fine Chemicals), $5 \mathrm{mM}$ $\mathrm{MgCl}_{2}, 2.5 \mathrm{U}$ of Moloney murine leukemia virus reverse transcriptase (RT) (Bethesda Research Laboratories, Gaithersburg, MD), and $4 \mathrm{U}$ of RNase inhibitor (Boehringer Mannheim Biochemicals, Indianapolis, IN). The tubes were incubated at room temperature for $10 \mathrm{~min}$, at $42^{\circ} \mathrm{C}$ for $15 \mathrm{~min}$, at $99^{\circ} \mathrm{C}$ for $5 \mathrm{~min}$, and at $5^{\circ} \mathrm{C}$ for $5 \mathrm{~min}$. Each set of cDNA synthesis experiments included a control sample in which all reagents except RNA were present.

Polymerase chain reaction (PCR). The cDNA products were amplified by PCR $(29,30)$. The oligonucleotide primers used for the amplification and the annealing temperatures for each PCR are listed in Table I. Each reaction mixture contained the $20 \mu \mathrm{l}$ of cDNA from the RT reaction, $1 \times$ Taq buffer, $2.5 \mathrm{U}$ of Taq polymerase (Boehringer Mannheim Biochemicals), $50 \mathrm{pmol}$ of each oligonucleotide primer, and distilled water to bring the final volume to $100 \mu \mathrm{l}$. For controls, we used 20 $\mu l$ of the reaction mixes from the RNA-less samples for $\mathrm{CDNA}$ synthesis (see previous section). $\mathrm{cDNA}$ samples were heated at $94^{\circ} \mathrm{C}$ for $3 \mathrm{~min}$ and then subjected to 35 cycles of denaturation $\left(94^{\circ} \mathrm{C}\right.$ for $\left.30 \mathrm{~s}\right)$, primer annealing (as indicated in Table I), and extension $\left(65^{\circ} \mathrm{C}\right.$ for $30 \mathrm{~s}$ ), followed by a final extension period of $7 \mathrm{~min}$. Nested RT-PCR products were generated for sequencing reactions, using the oligonucleotide primers F1R, F1L, F2R, and F2L. The sequences of these oligonucleotides and the PCR conditions have been described previously (31).

Hybridization with allele-specific oligonucleotides and PCR products. $20 \mu$ l of each RT-PCR sample were subjected to electrophoresis on a $1.4 \%$ agarose gel. Blots were prepared as previously described (28). Filters were hybridized for $18 \mathrm{~h}$ with $5 \times 10^{6} \mathrm{cpm} / \mathrm{ml}$ of ${ }^{32} \mathrm{P}$ end-labeled oligonucleotides or $5 \times 10^{7} \mathrm{cpm} / \mathrm{ml}{ }^{32} \mathrm{P}$ random-primed specific genomic DNA-PCR products. The blots were washed twice at room temperature for $5 \mathrm{~min}$, followed by two 15 -min washes at $55^{\circ} \mathrm{C}$.

Identification of the W1282X mutation by MnlI digestion. $25 \mu \mathrm{l}$ of RT-PCR products of exons 19-21 was digested with Mnll restriction endonuclease for $18 \mathrm{~h}$ at $37^{\circ} \mathrm{C}$ and subjected to electrophoresis on $1.7 \%$ agarose gels. Blots were prepared and hybridized with exon 20 genomic DNA-PCR products as described above.

$R T$-PCR sequence determination. Nested RT-PCR products of exons 19-21 eluted from 5\% polyacrylamide gels were extracted with phenol/chloroform and subjected to the dideoxy chain termination sequencing method (32) using the Sequenase ${ }^{\mathrm{TM}}$ kit (U. S. Biochem. Corp., Indianapolis, IN) with the F2R oligonucleotide as the sequencing primer.

\section{Results}

cDNA reverse transcribed from total nasal epithelial RNA was analyzed in five CF patients homozygous for the nonsense mutation W1282X, two CF patients homozygous for the $\Delta \mathrm{F} 508$ mutation, and a normal individual. The CF patients homozygous for the W1282X mutation were 1-32 yr old, all with pancreatic insufficiency. The pulmonary disease was mild in some patients and severe in the others. This variability was not correlated with age. Three regions of the CF gene were amplified by RT-PCR: upstream to the W1282X mutation, exons 9-11 (region I); flanking the mutation, exons 19-21 (region II); and downstream to the mutations, exon 21-23 (region III). The sequences of the oligonucleotide primers used in the RT-PCRs are listed in Table I. No PCR products could be seen on the ethidium bromide-stained agarose gels. Therefore, the RTPCR products generated from regions I, II, or III were blotted and hybridized to the DNA-PCR products of exon 10,20 , or 21 , respectively. The $\beta$-actin gene was amplified as a control for the overall amount of RNA extracted from the scraped nasal cells. These amplified products were hybridized to actin PCR products. DNA fragments of the predicted sizes were detected in all three regions of the $\mathrm{CF}$ and the actin genes in all patients (Fig. 1). The hybridization results revealed the existence of RTPCR products from CF patients homozygous for the W1282X mutation. These results were verified by direct sequencing of the RT-PCR products generated from patients homozygous for the W1282X mutation. Nested RT-PCR was performed between exons 19 and 24 (as described in Methods) and the products were directly sequenced. The complete expected cDNA sequence, with the W1282X mutation, was found in all the RT-PCR products from patients homozygous for this mutation (Fig. 2).

To study the relative levels of CFTR transcripts from W1282X, $\triangle \mathrm{F} 508$, and the normal alleles, cDNA from two patients heterozygous for both the $\triangle F 508$ and the W1282X mutations and from two healthy carriers of the W1282X mutation was amplified. In addition, cDNA was amplified from the same individuals, homozygous for either the $\mathrm{W} 1282 \mathrm{X}$ mutation or the normal allele, as in the previous experiments. The amplified region was between exons 19 and 21 . For controls, exon 20 genomic DNA was amplified from individuals homozygous for 


\begin{tabular}{|c|c|c|c|}
\hline Region & & Primer $\left(5^{\prime} \rightarrow 3\right)$ & Annealing temperature \\
\hline & \multicolumn{3}{|c|}{ PCR oligonucleotide primers } \\
\hline \multirow[t]{2}{*}{ Actin } & 998 & TGAAACAACATACAATTCCATCATGAAGTGTGAC & $65^{\circ} \mathrm{C}$ \\
\hline & 886 & AGGAGCGATAATCTTGATCTTCATGGTGCT & \\
\hline \multicolumn{4}{|c|}{ CFTR exons } \\
\hline \multirow[t]{2}{*}{$9-11$} & X9B & TACTCCTGTCCTGAAAGA & $50^{\circ} \mathrm{C}$ \\
\hline & $542 \mathrm{~N}$ & ACCTTCTCCAAGAACT & \\
\hline \multirow[t]{2}{*}{$19-21$} & C1-1D & CCAAACCATACAAGAAT & $50^{\circ} \mathrm{C}$ \\
\hline & $\mathrm{X} 21 \mathrm{~A}$ & GATCACTCCACTGTTCAT & \\
\hline \multirow[t]{7}{*}{$21-23$} & $\mathrm{X} 21 \mathrm{~B}$ & TTGGATCCCTATGAACAG & $50^{\circ} \mathrm{C}$ \\
\hline & $\mathrm{X} 23 \mathrm{~A}$ & TTACTGTGCAATCAGCAA & \\
\hline & & & Washing temperature \\
\hline & \multicolumn{3}{|c|}{ Oligonucleotides for hybridization } \\
\hline & WN & CAACAGTGGAGGAAAG & $55^{\circ} \mathrm{C}$ \\
\hline & WM & CAACAGTGĀAGGAAAG & $55^{\circ} \mathrm{C}$ \\
\hline & $\mathbf{W M}^{\prime}$ & GGCTTTCCT̃TCACTGT & $55^{\circ} \mathrm{C}$ \\
\hline
\end{tabular}

the W1282X mutation, from individuals heterozygous for the W1282X mutation and a normal allele, and from individuals carrying two normal alleles. Only PCR products from the DNA controls could be detected on the ethidium bromide-stained gel, therefore, the PCR products were blotted and hybridized to specific oligonucleotides detecting either the W1282X mutation (WM) or the normal sequence at this site (WN) (see Table I).

Surprisingly, the W1282X alleles could not be detected by the WM oligonucleotide in any of the RT-PCR products. Hybridization signals of the predicted sizes were detected only on the DNA-PCR controls (data not shown). Weak hybridization signals were detected in RT-PCR products of individuals carrying the normal exon 20 sequences using the WN oligonucleotide probe. An 'oligonucleotide $\left(\mathrm{WM}^{\prime}\right)$ from the antisense strand was designed to detect the W1282X mutation (Table I), but no hybridization to the $\mathrm{W} 1282 \mathrm{X}$ allele could be detected with this oligonucleotide either.

Hybridization to oligonucleotide probes designed to differentiate between CF the $\mathrm{W} 1282 \mathrm{X}$ allele and the normal allele was not sensitive enough for our purposes. Therefore, we

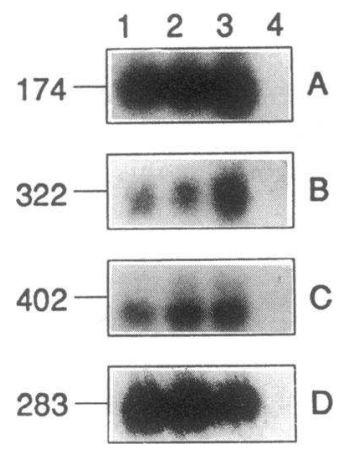

Figure 1. mRNA analysis by RT-PCR and subsequent hybridization with PCR products. (Lane 1) Normal control, (lane 2) $\Delta \mathrm{F} 508 / \Delta \mathrm{F} 508$, (lane 3) W1282X/W1282X, (lane 4) RNAless. $(A)$ RT-PCR products of the $\beta$ actin gene. $(B)$ RT-PCR products of exons 9-11 (region I) of the CF gene hybridized with genomic PCR products of exon 10. (C) RT-PCR products of exons 19-21 (region II) of the CF gene hybridized with genomic PCR products of exon 20. (D) RTPCR products of exons 21-23 (region

III) of the CF gene hybridized with genomic PCR product of exon 21. The sizes (bp) of the RT-PCR products are marked on the left. adopted our original technique, in which we detected RT-PCR products using genomic DNA-PCR products as probes. We took advantage of the fact that the W1282X mutation destroys a recognition site for the restriction enzyme MnlI. We digested the RT-PCR products from exons 19-21 with MnlI, before gel electrophoresis, blotting, and hybridization. To study the relative levels of CFTR transcripts from W1282X, $\triangle F 508$ and the normal alleles, relative intensity of the radioactive bands representing the $\mathrm{W} 1282 \mathrm{X}$ and the normal or the $\Delta \mathrm{F} 508$ alleles in each lane were analyzed. For this analysis we have enlarged the group of individuals heterozygous for the W1282X mutation. Thus, in these experiments were included two patients heterozygous for the $\Delta \mathrm{F} 508$ and W1282X mutations, five healthy carriers of the W1282X mutation, three patients homozygous for the W1282X mutation, and one patient homozygous for the $\Delta$ F508 mutation. The RT-PCR products were from the same batches as had failed to give signals when hybridized with

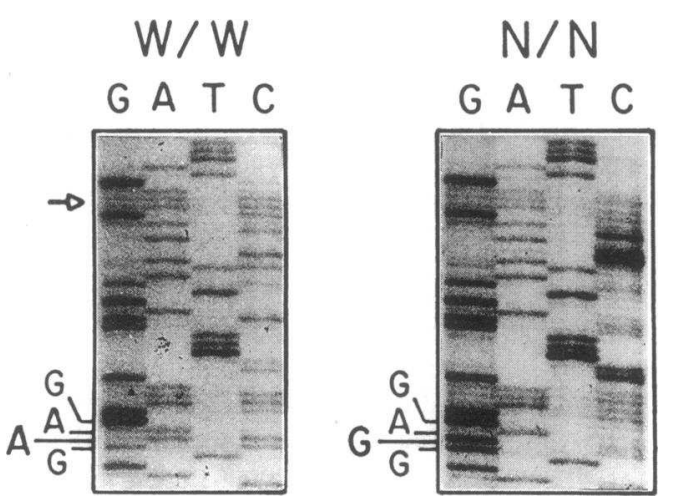

Figure 2. RT-PCR sequence around the $\mathrm{W} 1282 \mathrm{X}$ mutation. The $\mathrm{G} \rightarrow \mathrm{A}$ mutation is shown in boldface letters. The sequence was derived from the coding strand. $W / W$, mutated sequence derived from a patient homozygous for the $\mathrm{W} 1282 \mathrm{X}$ mutation. $N / N$, normal sequence derived from normal control. The arrow points to the cDNA junction between exons 20 and 21 . 
oligonucleotide probes (see previous section) and from additional three carriers of the $\mathrm{W} 1282 \mathrm{X}$ mutation. The blots were hybridized to exon 20 genomic DNA-PCR products. The restriction map of the amplified region is shown in Fig. 3. The Mnll-digested RT-PCR products from the heterozygous individuals revealed two bands: one of $204 \mathrm{bp}$ and the other a 99 + 105-bp doublet; the 99- and the 105-bp bands are inseparable on the gel (Fig. 4). The first band is the expected size for the W1282X allele and the second band is of the expected size for the $\Delta \mathrm{F} 508$ or the normal alleles. The MnlI-digested RT-PCR products from individuals homozygous for the $\mathrm{W} 1282 \mathrm{X}$ mutation revealed only the 204-bp band, and those from individuals homozygous for the $\Delta \mathrm{F} 508$ detected only the $99+105-b p$ doublet. The 27-bp band could not be detected as it migrated out of the gel (see Fig. 3). Densitometry analysis of two individuals heterozygous for the $\mathrm{W} 1282 \mathrm{X}$ and the normal alleles are presented in Fig. 4, lanes 1 and 7 . The analysis revealed a ration of 2:1 for the W1282X to the normal allele in each lane. This experiment was repeated by analysis of three additional individuals heterozygous for the $\mathrm{W} 1282 \mathrm{X}$ and the normal allele. The densitometry analysis revealed also a 2:1 ratio between the $\mathrm{W} 1282 \mathrm{X}$ and the normal allele in each lane (data not shown). Analysis of two individuals heterozygous for the W1282X and the $\Delta \mathrm{F} 508$ mutations are presented in Fig. 4 , lanes 2 and 6 . The analysis revealed in each lane a 1:3 ratio between the W1282X and $\Delta$ F508 alleles, respectively. Subsequently, the same blot was hybridized to the exon 21 DNA-PCR product, which is expected to hybridize to the same 204- and 99-bp bands (Figs. 3 and 4). The pattern of bands was identical to that detected by the exon 20 DNA-PCR probe, confirming that the 105 - and the 99-bp bands are indeed inseparable on the gel (data not shown). In addition, the ratio between the $\mathrm{W} 1282 \mathrm{X}$ and the $\Delta \mathrm{F} 508$ or the normal alleles, in each lane, were the same as those revealed by exon 20 DNA-PCR probe. In summary, our results show that in patients heterozygous for the W1282X and the $\Delta \mathrm{F} 508$ or the normal alleles, similar levels of mRNA from the two alleles are found in each individual.

\section{Discussion}

In this study we present an analysis of the CF mRNA levels in nasal epithelial cells from CF patients carrying the nonsense mutation, W1282X. Altogether, $19 \mathrm{CF}$ chromosomes carrying the W1282X mutation were studied, from patients with various degrees of pulmonary disease. Understanding the effect of the nonsense mutation W1282X on mRNA levels is significant to the understanding of the phenotype-genotype association in this group of patients. cDNA reversed transcribed from
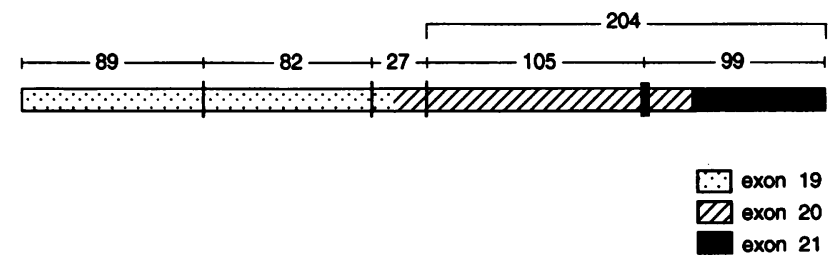

Figure 3. RT-PCR map of exons 19-21 (region II). The MnlI sites are represented by vertical bars. The polymorphic site, which is destroyed by the W1282X mutation, is represented by a thick bar. The sizes of the digested fragments are indicated above.

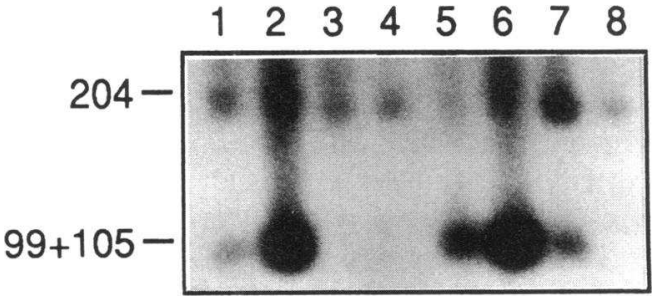

Figure 4. Analysis of relative mRNA levels in heterozygous individuals carrying the W1282X mutation. Hybridization of DNA-PCR products of exon 20 with MnlI digested RT-PCR products from region II generated from: two healthy individuals heterozygous for the W1282X mutation (lanes 1 and 7); two CF patients heterozygous for the W1282X and $\triangle \mathrm{F} 508$ mutations (lanes 2 and 6 ); three $\mathrm{CF}$ patients homozygous for the W1282X mutation (lanes 3, 4, and 8); and a CF patient homozygous for the $\Delta \mathrm{F} 508$ mutation (lane 5). The sizes (bp) of the digested fragments are indicated.

nasal epithelial total RNA was revealed in five CF patients homozygous for the nonsense mutation W1282X using exon 20 DNA-PCR products as probes. The hybridization results revealed the existence of RT-PCR products from CF patients homozygous for the W1282X mutation (Fig. 1). Furthermore, sequencing of the cDNA-nested PCR products generated from the homozygous patients carrying the W1282X mutation showed the expected sequence with the W1282X mutation (Fig. 2). These results indicate that the level of mRNA in patients homozygous for the W1282X mutation is not severely reduced by the premature termination mutation, as was found for termination mutations in other genes.

Exon skipping due to missense and nonsense mutations has been shown in several genes (33-35). The results of our study also exclude the possibility of exon skipping due to the W1282X nonsense mutation.

We initially examined the relative levels of mRNA transcripts in individuals heterozygous for the W1282X and the $\Delta \mathrm{F} 508$ or the normal alleles by allele-specific oligonucleotide hybridization. Unexpectedly, the RT-PCR products of the W1282X allele could not be detected. Even RT-PCR products that had previously been detected by exon 20 DNA-PCR product as the probe could not be detected by allele specific oligonucleotide hybridization. The reason for this discrepancy is not clear to us. It might be the result of interference by secondary structure of the oligonucleotide, the inability of the oligonucleotide to detect low levels of RT-PCR products, or both.

However, we were able to detect the expected size RT-PCR bands generated from individuals heterozygous for the W1282X mutation by MnlI digestion and subsequent hybridization to exon 20 and 21 DNA-PCR products. In heterozygotes who carry both the W1282X and the normal alleles, the levels of the RT-PCR from the W1282X alleles were slightly higher than those of the $\Delta F 508$ alleles (ratio of 2:1, respectively). In heterozygotes who carry the W $1282 \mathrm{X}$ and the $\Delta \mathrm{F} 508$ alleles, the levels of the RT-PCR from the W1282X allele were slightly lower than those from the $\Delta \mathrm{F} 508$ allele (3:1, respectively). Since the number of patients in each group was small, the significance of these fluctuations could not be evaluated. It is, however, clear that the mRNA levels of the W1282X allele are not severely reduced. Furthermore, our results indicate that negative hybridization results using oligonucleotides as probes must be confirmed by other methods. 
Recently, Rolfini et al. (36) reported that in patients homozygous for another nonsense mutation in exon $20, \mathrm{R} 1262 \mathrm{X}$, the mRNA levels seems very similar to those obtained in normal and $\Delta$ F508 homozygous patients. In addition, Hamosh et al. (37) reported that patients heterozygous for the W1282X mutation have severe deficiency of mRNA derived from the W1282X allele. This conclusion was based on hybridization with an oligonucleotide specific for the W1282X mutation. Severe deficiency of mRNA derived from another nonsense mutation, G542X, was also reported in that study. In addition, in a previous study (27), severe deficiency of mRNA of the R553X and W1316X mutations was reported; these conclusions were also based on hybridization to oligonucleotides. Further studies using different detection tests are needed to verify the conclusions from the negative results obtained for the G542X, W1316X, and the R553X mutations.

The results of our study on CF patients carrying the W1282X mutation together with the results of the study on patients homozygous for the R1262X mutation suggest that mutations in exon 20 of the CFTR gene have no effect on mRNA levels. Since these two mutations are located towards the $3^{\prime}$ end of the gene, the results are compatible with the polar effects of nonsense mutations found in other genes (16). However, more studies on the effects of nonsense mutations towards the $5^{\prime}$ end of the CF gene are needed before general conclusions can be drawn. It is expected that a truncated protein would be produced from the W1282X and the R1262X alleles.

Patients homozygous for the W1282X mutation were found to have severe presentations of the CF disease, like patients homozygous for the $\Delta F 508$ mutation (28). The results of our study indicate that the severe clinical phenotype is not necessarily due to a null phenotype resulting from severe deficiency of mRNA. In addition, it is important to emphasize that the pulmonary disease of the patients in this study varied and was not correlated with age. The oldest patient in the group was $35 \mathrm{yr}$ old and his pulmonary disease was rather mild (forced expiratory volume in $1 \mathrm{~s}=45 \%$ ). We have shown that this variability in the pulmonary disease is not a result of variable mRNA levels. Thus, the severity progression and variability of pulmonary disease are affected by other, as yet unknown factors.

\section{Acknowledgments}

We thank Drs. Lap-Chee Tsui, Johanna Rommens, and Ann Harris for providing oligonucleotide primers, and Dr. Shoshana Klein for helpful discussions.

This study was supported by grants from the Thyssen Foundation and the Israeli Foundation for Sciences and Humanities (to B. Kerem).

\section{References}

1. Lehrman, M. A., W. J. Schneider, M. S. Brown, C. G. Davis, A. Elhammer, D. W. Russell, and J. L. Goldstein. 1987. The Lebanese allele at the low density lipoprotein receptor locus. J. Biol. Chem. 262:401-410.

2. Fojo, S. S., P. Lohse, C. Parrott, G. Baggio, C. Gabelli, F. Thomas, J. Hoffman, and H. B. Brewer, Jr. 1989. A nonsense mutation in the apolipoprotein C II gene in a patient with apolipoprotein deficiency. J. Clin. Invest. 84:12151219.

3. Nilsson, G., J. G. Belasco, S. N. Cohen, and A. von Gabain. 1987. Effect of premature termination of translation on mRNA stability depends on the site of ribosome release. Proc. Natl. Acad. Sci. USA. 84:4890-4894.
4. Losson, R., and F. Lacroute. 1979. Interference of nonsense mutations with eukaryotic messenger RNA stability. Proc. Natl. Acad. Sci. USA. 76:5134-5137.

5. Baumann, B., M. J. Potash, and G. Kohler. 1985. Consequences of frameshift mutations at the immunoglobulin heavy chain locus of the mouse. $E M B O$ (Eur. Mol. Biol. Organ.) J. 4:351-359.

6. Atweh, G. F., H. E. Brickner, X.-X. Zhu, H. H. Kazazian, Jr., and B. G. Forget. 1988. New amber mutation in a $\beta$-thalassemic gene with nonmeasurable levels of mutant messenger RNA in vivo. J. Clin. Invest. 82:557-561.

7. Baserga, S. J., and E. J. Benz, Jr. 1988. Nonsense mutations in the human beta-globin gene affect mRNA metabolism. Proc. Natl. Acad. Sci. USA. 85:20562060.

8. Humphries, R. K., T. J. Ley, N. P. Anagnou, A. W. Bauer, and A. W. Nienhaus. 1984. $\beta^{\circ}$-Thalassaemia gene: a premature termination codon causes $\beta$-mRNA deficiency without affecting cytoplasmic $\beta$-mRNA stability. Blood. 64:23-32.

9. Moschonas, N., E. DeBoer, F. G. Grosveld, H. H. M. Dahl, S. Wright, C. K. Shewmaker, and R. A. Flavell. 1981. Structure and expression of cloned $\beta^{\circ}$ thalassemic globin gene. Nucleic Acids Res. 9:4391-4401.

10. Orkin, S. H., and S. Goff. 1981. Nonsense and frame shift mutations in $\beta^{0}$-thalassaemia detected in cloned $\beta$-globin genes. J. Biol. Chem. 256:97829784.

11. Takeshita, K., B. G. Forget, A. Scarpa, and E. B. Benz, Jr. 1984. Intranuclear defect in $\beta$-globin mRNA accumulation due to a premature translation termination codon. Blood. 84:13-22.

12. Daar, I. O., and L. E. Maquat. 1988. Premature translation termination mediates triose phosphate isomerase mRNA degradation. Mol. Cell. Biol. 8:802813.

13. Globerman, H., M. Amor, K. L. Parker, M. I. New, and P. C. White. 1988. Nonsense mutation causing steroid 21-hydroxylase deficiency. J. Clin. Invest. 82:139-144.

14. Maquat, L. E., A. J. Kinniburgh, E. A. Rachmilewitz, and J. Ross. 1981 Unstable $\beta$-globin mRNA in mRNA-deficient $\beta^{0}$ thalassaemia. Cell. 27:543-553.

15. Urlaub, G., P. J. Mitchell, C. J. Ciudad, and L. A. Chasin. 1989. Nonsense mutations in the dihydrofolate reductase gene affect RNA processing. Mol. Cell. Biol. 9:2868-2880.

16. Atwater, J. A., R. Wisdom, and I. M. Verma. 1990. Regulated mRNA stability. Annu. Rev. Genet. 24:519-541.

17. Ramirez, F., D. Starkman, A. Bank, H. Karem, G. Cividalli, and E. A. Rachmilewitz. 1978. Absence of $\beta$ mRNA in $\beta^{\circ}$ thalassaemia in Kurdish Jews. Blood. 52:735-739.

18. Boat, T. F., M. J. Welsh, and A. L. Beaudet. 1989. Cystic fibrosis. In The Metabolic Basis of Inherited Disease. 6th ed. C. L. Scriver, A. L. Beaudet, W. S. Sly, and D. Valle, editors. McGraw-Hill Inc., New York. 2649-2680.

19. Rommens, J. M., M. C. Iannuzzi, B. Kerem, M. L. Drumm, G. Melmer, M. Dean, R. Rozmahel, J. L. Cole, D. Kennedy, N. Hidaka, M. Zsiga, M. Buchvald, J. R. Riordan, and L.-C. Tsui. 1989. Identification of the Cystic fibrosis gene: chromosome walking and jumping. Science (Wash. DC). 245:1059-1064.

20. Riordan, J. R., J. M. Rommens, B. Kerem, N. Alon, R. Rozmahel, Z. Grzelczak, J. Zielenski, S. Lock, N. Plavsic, J-L. Chou, M. C. Drumm, M. C. Iannuzzi, F. S. Collins, and L.-C. Tsui 1989. Identification of the Cystic fibrosis gene: cloning and characterization of complementary DNA. Science (Wash. DC). 245:1066-1073.

21. Kerem, B., J. M. Rommens, J. A. Buchanan, D. Markiewicz, T. K. Cox, A. Chakravarti, M. Buchwald, and L-C. Tsui. 1989. Identification of the Cystic fibrosis gene: genetic analysis. Science (Wash. DC). 245:1073-1080.

22. Kerem, B., J. A. Buchanan, P. Durie, M. L. Corey, H. Levison, J. M. Rommens, M. Buchwald, and L-C. Tsui. 1989. DNA marker haplotype association with pancreatic sufficiency in cystic fibrosis. Am. J. Hum. Genet. 44:827834.

23. Kerem, E., M. Corey, B. Kerem, J. M. Rommens, D. Markiewicz, H. Levison, L-C. Tsui, and P. Durie. 1990. The relationship between genotype and phenotype in cystic fibrosis-analysis of the most common mutation ( $\triangle$ F508). $N$. Engl. J. Med. 323:1517-1522.

24. Santis, G., L. Osborne, R. A. Knight, and M. E. Hodson. 1990. Linked marker haplotypes and the $\Delta \mathrm{F} 508$ mutation in adults with mild pulmonary disease and cystic fibrosis. Lancet. 335:1426-1429.

25. Tsui, L-C. 1992. The spectrum of cystic fibrosis mutations. Trends Genet. 8:392-398.

26. Kristidis, P., D. Bozon, M. L. Corey, D. Markiewicz, J. Rommens, L-C. Tsui, and P. Durie. 1992. Genetic determination of exocrine pancreatic function in cystic fibrosis. Am. J. Hum. Genet. 50:1178-1184.

27. Hamosh, A., B. C. Trapnell, P. L. Zeitlin, C. Montrose-Rafizadeh, B. J. Rosenstein, R. G. Crystal, and G. R. Cutting. 1991. Severe deficiency of cystic fibrosis transmembrane conductance regulator messenger RNA carrying nonsense mutations R553X and W1316X in respiratory epithelial cells of patients with cystic fibrosis. J. Clin. Invest. 88:1880-1885.

28. Shoshani, T., A. Augarten, E. Gazit, N. Bashan, Y. Yahav, Y. Rivlin, A. Tal, H. Seret, L. Yaar, E. Kerem, and B. Kerem. 1992. Association of a nonsense 
mutation (W1282X), the most common mutation in the Ashkenazi Jewish cystic fibrosis patients in Israel, with presentation of severe disease. Am. J. Hum. Genet. 50:222-228.

29. Saiki, R. K., S. Scharf, F. Faloona, K. B. Mullis, G. T. Horn, H. A. Erlich, and N. Arnheim. 1985. Enzymatic amplification of beta globin genomic sequences and restriction site analysis for diagnosis of sickle cell anemia. Science (Wash. DC). 230:1350-1354.

30. Saiki, R. K., S. H. Gelfand, S. Stoffel, S. J. Scharf, R. Higuchi, G. T. Horn, K. B. Mullis, and H. A. Erlich. 1988. Primer-directed enzymatic amplification of DNA with a thermostable DNA polymerase. Science (Wash. DC). 239:487-491.

31. Chalkley, G., and A. Harris. 1991. Lymphocyte mRNA as a resource for detection of mutations and polymorphisms in the CF gene. J. Med. Genet. 28:777-780.

32. Winship, P. R. 1989. An improved method for directly sequencing PCR amplified material using dimethyl sulfoxide. Nucleic Acids Res. 17:1266-1269.

33. Dietz, H. C., D. Valle, C. A. Francomano, R. J. Kendzior, Jr., R. E.
Pyeritz, and G. R. Cutting. 1993. The skipping of constitutive exons in vivo induced by nonsense mutations. Science (Wash DC). 259:680-686.

34. Matsuo, M., T. Masumura, H. Nishio, T. Nakajima, Y. Kitoh, T. Takumi, J. Koga, and H. Nakamura. 1991. Exon skipping during splicing of dystrophin mRNA precursor due to an intraexon deletion in the dystrophin gene of Duchenne muscular dystrophy kobe. J. Clin. Invest. 87:2127-2131.

35. Wakamatsu, N., H. Kobayashi, T. Miyatake, and S. Tsuji. 1992. A novel exon mutation in the human $\beta$-hexosaminidase $\beta$ subunit gene affects 3 ' splice site selection. J. Biol. Chem. 267:2406-2413.

36. Rolfini, R., M. C. Dechecchi, A. Tamanini, and G. Cabrini. 1992. Detection of CFTR mRNA in nasal polyp from a R1162X CF homozygote. Pediatr. Pulmonol. S8:253.

37. Hamosh, A., B. J. Rosenstein, and G. R. Cutting. 1992. CFTR nonsense mutations G542X and W1282X are associated with severe reduction of CFTR mRNA in respiratory epithelial cells. Hum. Mol. Genet. 1:542-544. 